\title{
Indonesian EFL Teachers' Familiarity with and Opinion on the Internet-Based Teaching of Writing
}

\author{
Bambang Yudi Cahyono ${ }^{1} \&$ Ira Mutiaraningrum ${ }^{2}$ \\ ${ }^{1}$ English Department, State University of Malang, East Java, Indonesia \\ ${ }^{2}$ English Department, Tanjungpura University of Pontianak, West Kalimantan, Indonesia \\ Correspondence: Ira Mutiaraningrum, English Department, Tanjungpura University of Pontianak, West \\ Kalimantan, Indonesia. Tel: 62-857-5029-1252. E-mail: ira.mutiaraningrum@gmail.com
}

\author{
Received: October 25, 2015 Accepted: December 17, 2015 Online Published: December 18, 2015 \\ doi:10.5539/elt.v9n1p199 URL: http://dx.doi.org/10.5539/elt.v9n1p199
}

\begin{abstract}
The use of the Information and Communication Technology (ICT) especially the Internet has been a common practice in education. However, research studies show that the Internet has not been frequently used in the teaching of English as a foreign language (EFL) writing, especially in the Indonesian context. This study aimed to find out whether or not Indonesian EFL teachers are familiar with the Internet-based techniques for the teaching of writing. In addition, it investigated their opinions on the Internet-based techniques of teaching of writing. This study involved 17 EFL teachers from various parts of the country who were asked about their experiences and opinions dealing with the Internet-based teaching of writing. The results of the study showed that almost half of the teachers admitted that they have used Internet facilities for the teaching of writing. The other EFL teachers either have indirect involvement with the teaching of writing using Internet application or have never used Internet applications at all. However, these teachers had intention to teach writing by applying Internet-based techniques for their future practices. The study also showed that Indonesian EFL teachers valued the Internet-based teaching of writing as this practice benefits the students in terms of their writing quality and quantity, autonomy, flexibility, as well as confidence. This implies that with the development of advanced ICT, there is a hope that students' learning of writing could be improved well.
\end{abstract}

Keywords: Indonesia EFL teachers, familiarity, opinion, internet-based teaching of writing

\section{Introduction}

In the field of education, the use of Information and Communication Technology (ICT) has become one of the current norms. The development of ICT, especially the Internet, has affected how the students learn, how they interact with teachers and other students, and how they deal with various aspects of their daily life. For the last five years only, many students have been familiar with Internet-based facilities varying from facebook, e-book, to tablet books, following the application of earlier Internet-based facilities such as email, websites, and webblogs. In Indonesia, Internet-based techniques of teaching and learning have been proposed to be included in the curricular component of English teacher education. For example, a research study reported by Cahyono and Widiati (2007) recommended teacher-training institutions to involve the integration of Internet-based facilities in the subjects that student teachers learn in their pre-service education (see Cahyono \& Widiati, 2007). In the same vein, a study reported by Legutke, Muller-Hartmann, and Ditfurth (2007) recommended that Internet-based facilities can be used as new knowledge base for English teacher education.

The Internet-based teaching of writing gains its popularity in which webblogs (Blackstone, Spiri, \& Naganuma, 2007; Eady \& Lockyer, 2013; Wu, 2014) and social media such as Facebook, Twitter, Wikis (Hadjerrouit, 2011; Hiew, 2012; Lundin, 2008; Yunus \& Salehi, 2012) are used in teaching writing. This is not surprising since internet-based teaching of writing is believed as the answer of many problems in teaching writing such as time limitation in teaching writing (Aliweh, 2011; Moloudi, 2011), inadequate media supporting writing (Bilal, Tariq, Din, Latif, \& Anjum, 2013) and lack of motivation (Erkan \& Saban, 2011; Gupta \&Wondemariam, 2011). Hence, ICT is used in teaching writing for its promising and prominent impact on students' writing (Deore, 2012; Mohamed \& Ayeche, 2011; Warnock, 2009).

Several studies have shown the emergence of the Internet-based teaching of writing. A report from the Pew 
Research Internet Project entitled "The Impact of Digital Tools on Student Writing and How Writing is Taught in Schools" in 2013 showed that the majority of teachers view Internet and digital technologies to have positive impact on student writing (Purcell, Buchanan, \& Friedrich, 2013). The use of ICT in the teaching of writing also encourages the communication among students and offers more opportunities for interaction and writing together which are more meaningful and less intimidating, especially for shy students (Purcell, Buchanan, Friedrich, 2013; Yang \& Cornelius, 2003). Writing online is also motivating in which it causes students to feel a responsibility towards their learners to create and maintain environments that motivate learners to continue learning even after the class (Aljumah, 2012).

In addition, the Internet-based teaching of writing stimulates collaborations and thinking skills. Collaborative activities using the Internet enable students to form ideas, exchange thoughts and write together in a meaningful and autonomous way (Blackstone et al., 2007; Eady \& Lockyer, 2013). For example, peer reviews and peer comments activities in online discussion forum as the examples of Internet-based collaborative writing enable students to have an editor for their writing as well as being an editor (Blackstone et al., 2007). These kinds of activities involving peers to give feedback or comments obviously require students' deep thinking. In writing their thoughts, students are trained to critically write and choose important and relevant information due to the availability of various beneficial sources from the Internet (Deore, 2012; Mohamed \& Ayeche, 2011). Hence, both teachers and students are benefited from the Internet-based teaching of writing.

Despite the enormous help offered by the Internet and digital tools, computers and technology are still sources of fears and insecurity for many teachers all over the world (Laborda \& Royo, 2007). Teachers who are reluctant to use the Internet and digital tools are found everywhere in the world. This implies that the unavailability of technical support and facilities is not the only reason hindering teachers from maximizing the Internet in the teaching process. Reasons which inhibited teachers from maximizing the role of technology in the classroom that include the lack of time, budget limitation, need for training, and difficulty of incorporating technology in the classroom (Morehead \& LaBeau, 2005). The Internet and teaching process do not go hand in hand. Teachers do not know how to integrate the Internet in curriculum, especially in teaching writing in which handwriting becomes an easy and more practical way of teaching writing.

Investigating the teachers' familiarity with the Internet-based teaching of writing becomes important to see the current and future practice of the integration of the Internet into the teaching of writing. The results of the study are important in picturing the Indonesian EFL teachers' familiarity and opinion toward the use of Internet-based facilities in teaching writing and are pertinence to Indonesian educational quality, especially in teaching writing. Creating better understanding toward English teachers' familiarity with the Internet-based teaching of writing is important to meet the improvements of English teaching in Indonesia. In addition, examining the teachers' opinions on the benefits of the Internet-based teaching of writing is imperative considering the success of the integration of Internet-based facilities in the teaching of writing depends greatly on the attitude of the teachers who administer the class. This article aims to gauge Indonesian EFL teachers' familiarity with and opinions on the Internet-based teaching of writing. More particularly it seeked to find out:

(1) to what extent English teachers are familiar with the Internet-based teaching of writing, and

(2) how English teachers perceive the benefits of the Internet-based teaching of writing.

\section{Method}

This study describes Indonesian EFL teachers' familiarity with the Internet-based teaching of writing and their opinions on the potential benefits of techniques in Internet -based teaching of writing for the improvement of the students' ability in writing.

The study involved 17 Indonesian EFL teachers who come from different part of Indonesia and teach various level of education from elementary school level up to University level (see Appendix A). The lengths of teaching English are varied from 5 to 10 years. They were taking "The Teaching of Writing" course at the graduate program in English Language Teaching at State University of Malang. The two-credit course aims to provide the EFL teachers with theoretical background of the teaching of writing and practical application of the theories in the English classroom. As written in the Catalogue of the English Department (2011: 57), the course description is as follows:

This course is aimed to provide students with theoretical background of the teaching of writing and practical application of the theories in the English classroom. The theories include the product approach, the process writing approach, and the genre-based approach. Based on these approaches, techniques of teaching writing are identified, investigated, and applied in the teaching of writing. From the beginning, the students are made alert 
that, ideally, the teachers of writing are productive writers. Therefore, the students are encouraged to improve their skills of writing by applying principles of academic writing and English rhetoric.

The course activities include discussion on theories in the teaching of writing, teaching writing at various levels, and the use of technology in the teaching of writing. With regard to the use of technology in the teaching of writing more specifically, the students were introduced to the discussion of Ferris and Hedgcock's (1998) chapter on "Technology in the Writing Class: Uses and Abuses." Ferris and Hedgcock's chapter deals discusses the advantages and disadvantages in using technology in the writing classroom, reviews research studies on computer-assisted writing, and highlights pedagogical issues in computer-assisted writing instruction. However, because the source material from Ferris and Hedgcock was published long time ago, there was no discussion focusing on the Internet-based teaching of writing. Thus, there is not much information on whether or not the EFL teachers involved in this study have been familiar with the Internet-based teaching of writing and how they perceived the benefits of the Internet-based teaching of writing.

In order to explore issues on the use of the Internet in the teaching of writing, at the end of the semester, the English teachers who were also graduate students were asked two questions formulated in the following prompt:

In the past, writing was closely related to the activity of hand-writing. Currently, with the development of Information and Communication Technology, writing can be done virtually through the Internet. (1) Do you have any idea/experience of designing a writing task on an online basis? Explain your idea/experience; (2) In your opinion, what are the strengths (NOT weaknesses) of the online writing task?

\section{Results}

The results of the study are described in terms of the English teachers' familiarity with Internet-based teaching of writing and their opinions on the Internet-based teaching of writing for the improvement of the students' ability in writing.

\subsection{English Teachers' Familiarity with the Internet-based Teaching of Writing}

In terms of the EFL teachers' familiarity with techniques in Internet-based teaching of writing, the results of the study show that the EFL teachers involved in this study falls into three categories: (1) EFL teachers with experiences in the Internet-based teaching of writing, (2) EFL teachers who are familiar with some techniques in the Internet-based teaching of writing, and (3) EFL teachers without experience in the Internet-based teaching of writing. The results of the study are presented in a greater detail according to each of the categories. Pseudonyms are used to refer to the English teachers involved in this study.

From 17 teachers, eight EFL teachers have their own experiences in applying Internet-based teaching of writing. The Internet-based applications that have been used for various purposes in the teaching of writing are as follows:

- Assigning the students to write a simple introduction and send their simple introduction to the teacher by using email. (Tatik)

- $\quad$ Asking the students to use an online magazine as a basis to write a descriptive text. (Miko)

- Asking the students to submit their writing product in Facebook Notes and to tag the notes to the other students. (Dina)

- $\quad$ Teaching participants of English Access Microscholarship using MyiZonelab, a program for integrated skill course produced by Pearson/Longman. (Elva)

- Asking the students to write their holiday experiences and publish the writing product (with pictures) in Facebook (Asfi)

- Asking the students to create blogs and ask them to post their writing products in the blogs. (Agam)

- Creating a mailing list in yahoo group to provide students with a medium to share ideas on any kind of topics to optimize their English learning. (Wigi)

- Improving the students' writing ability to write recount texts by using Facebook. (Rana)

Three of the EFL teachers are familiar with the use of some Internet-based applications because of their collaboration with colleagues or family members. The Internet-based applications that have been known for various purposes in the teaching of writing are as follows:

- Attending a course on essay writing integrating face-to-face instruction on planning, drafting, editing and revising processes of writing and publishing the final writing product in Facebook (Sherly) 
- Asking to the students to write a love letter and publish it on their blogs (Teti)

- Using Google Docs to create, share and edit students' writing products online (Erra)

The other six EFL teachers did not have any experience in using Internet-based applications, but all of them were eager to apply their ideas in using Internet-based facilities such as email, blog, or social media. The Internet-based applications that these English teachers might do in the future for various purposes in the teaching of writing are as follows:

- An idea to provide non English department students with a writing task asking them to write various topics through blogs (Ruzki)

- An idea in using Yahoo! Messenger to upload a writing task and to ask the students to find some necessary resources in the Internet. (Malia)

- An idea to have a blog or a facebook page to design a task, and to have a discussion and feedback openly (Dyan)

- An idea to design a writing task and ask the students to send their draft to the teacher by email for feedback before they finally publish their writing product in their Facebook account (Meira)

- An idea in using Facebook as the teaching of writing to involve the students in giving comment and feedback on the other students' work (Sakir)

- Asking the students to send their writing product to the teacher so that the teacher can provide feedback before the final draft is sent to social networking such as Twitter, Facebook, or Kaskus (Raza)

It is evident from the results of the study that not all of the teachers have experiences in applying Internet-based teaching of writing. This may lead us to the conclusion that the spread of advanced technology in teaching does not touch many places in Indonesia. However, English teachers who have not applied any Internet-based teaching of writing have thought about possible application of Internet-based teaching of writing in the future.

\subsection{English Teachers' Opinions on the Internet-based Teaching of Writing}

Interestingly, regardless of their background experiences, all English teachers have positive responses to the application of the Internet-based teaching of writing. More specifically, the responses of English teachers are presented in the following.

The Internet-based teaching of writing leads to improvement of the students' ability in writing. For example, Teacher 15 (Sakir) stated, "Students can get more insights from the Internet while they are logging into the social network as their insights in prewriting so that they can develop their writing well later." In addition to this, Teacher 8 (Rana) provides a review of the research results on the effect of online teaching using Facebook on the improvement of the students' ability in writing. She concluded,

"The use of Facebook in the publishing stage of process-based essay writing activities enhanced the skill in writing English essays ... that is because they were encouraged to do their best in writing as their essays could be read by other Facebookers."

Apart from the improvement of the quality of the students' writing, Teacher 11 (Erra) stated that the length of the texts that the students write increases. As she stated, the provision of online writing task "motivates or stimulates students' interest to write again and again (increases writing quantity)."

In addition to improving students' ability in writing, Internet-based teaching of writing increases students' active learning. For example, Teacher 7 (Wigi) stated that the use of the Internet enables the students to be active in the process of learning. She stated, "It (online writing task) encourages active learning. By implementing online writing task, students can actively look for some online information to support their ideas in writing. They are also required to be active learners when they are doing the peer review." In the same vein, Teacher 1 (Tatik) stated that Internet-based teaching of writing makes students active not only individually, but also collaboratively. In her words,

The students are able to be active because they know what they want to write, when they want to, and how they write. Individually, the students have responsibility to their learning process. In collaboratve online, online tas encourages the students having responsibility for their review and negotiation process. (Teacher 1)

Moreover, Internet-based teaching of writing improves the students' motivation and interest in learning English. For example, Teacher 12 (Ruzki) argued that the students' interest in learning English can be boosted through the use of the Internet-based facilities. This teacher stated, "In my opinion, the strengths of the online writing task are fostering the students' interest in writing because lots of students' inherent interest in all things 
technological." More particularly, with regard to the use of online magazine in the teaching of English, Teacher 2 (Miko) states that "an online magazine is an appropriate technique in teaching how to write a descriptive text, because it makies our learners enthusiastic and interested in reading." Summarizing all of the teachers' opinions on the motivational value of Internet-based teaching of writing, Teacher 16 (Sakir) stated, "online basis has motivational power for students because it is enjoyable, interesting, meaningful, and interactive."

Internet-based teaching of writing also provides effciency in terms of place and time. As stated by Teacher 13 (Malia), Internet-based teaching of writing is practical as "the teacher and the students need not set a specific time when they should meet and discuss the task." In agreement with Malia, Teacher 3 (Dina) added, "Using Internet helps the students to work 24 hours which is opening great opportunities for writing teacher to set up interesting activities for the students which could be accomplished outside the constraining class hours." Similarly, Teacher 4 (Elva) stated, "The time constraint in doing the writing tasks can be solved by having the students doing them by their own in their free time." In her brief statement that summarizes the English teachers' opinions on this beneficial aspect, Teacher 14 (Dyan) stated, "The benefits are commonly to the time saving and economically transported."

Finally, through Internet-based teaching of writing, the students' work can be shown to public. As stated by Teacher 5 (Asfi), "The students can promote and show their work throughout the Internet. In this case, they have the chance to show their work to many people." Teacher 6 (Agam) added, "Their writing product will be posted in the Internet and anyone can read, at least their own friends in the class." With regard to the publication of the students' work into Facebook, Teacher 15 (Meira) stated that because the students know that their friends will read their online works, they would be more motivated "to write as good as possible and as careful as possible."

In short, as shown in the responses of the English teachers, Internet-based teaching of writing improves the students' writing in terms of quantity and quality, increases their interest in learning, boosts their active learning, provides flexible learning tasks in terms of place and time, and it raises their self-confidence as their writing products are accessible not only by their friends or classmates, but also other Internet users.

\section{Discussion}

From 17 EFL teachers in this study, eight teachers had experiences in teaching writing using Internet-based facilities. Seven of them teach at university level in different parts in Indonesia and the other one teaches at an English course. Since they came from different part of Indonesia, they have different academic circumstance and different supporting facilities in learning. However, they managed to use Internet-based applications such as email, online magazine, Facebook, MyZonelab, blog, and mailing list in yahoo to teach writing. Morever, their lengths of teaching English are less than five years, only one of them has been teaching English more than five years. It implied that apart from their different background and length of teaching English, teachers always have chance to use ICT, especially the Internet to support their teaching. Also, there are three teachers who are familiar with the use of the Internet in teaching writing, but they did not use it in their own classes. Those three teachers teach at university level and actually are familiar with the use of the Internet in teaching writing such as using Facebook, blogs, and Google Docs to create, edit, and share students' writing.

On the other hand, there are six teachers who have no experience in using the Internet to teach writing. Those teachers teach in various levels of education such as elementary school level teacher, English course instructor, and English teacher at university level. Their lengths of teaching English are varied. Two of them have been teaching English for less than five years, three teachers have been teaching for more than five years, and the other one has been teaching English for more than ten years. Compared to other teachers involved in this study, teachers who do not have experience in using the Internet to teach writing have been teaching English longer than other teachers. However, surprisingly they did not have any experience in using the Internet in teaching writing. We assume that the reason behind their unfamiliarity with Internet in teaching writing is because those teachers started teaching English when the use of media in learning English was not as popular as today. Unfortunately, they were unlikely to catch up with the recent issue in English language teaching which makes them unfamiliar with the use of the Internet in teaching writing. This phenomenon urges us to think of some efforts Indonesian government can do to ensure the quality of all teachers from various places with varied lengths of teaching all over Indonesia. However, despite their unfamiliarity with Internet-based teaching of writing, the teachers have positive attitudes towards the use of the Internet in teaching writing. Hence, we can conclude that those teachers do not use the Internet-based teaching of writing because they have insufficient knowledge toward the use of the Internet in teaching writing.

To conclude, the overall responses from the EFL teachers reflect positive attitudes towards the use of Internet-based teaching of writing. The responses indicate that whether the teachers are familiar with 
Internet-based teaching writing or not, they support the use of advanced technology in the teaching of writing. This study highlighted the teachers' positive opinions to the application of the Internet-based teaching of writing. According to the teachers, Internet-based application in teaching writing improves students' quality and quantity, fosters active learning, motivates students' learning, offers flexibility and raises students' confidence.

The EFL teachers agree that the use of Internet-based application in teaching writing may help students improve their writing quality and quantity (Fidaoui, Bahous \& Bacha, 2010). Practically, Internet-based teaching improved students' writing by providing the students chance in brainstorming to organize thought before writing, learning new vocabularies, and reducing spelling errors through spell-check features (Bani-Hani, Al-Sobh, \& Abu-Melhim, 2014; Yunus, Salehi, Sun, Yen \& Li, 2011). Also, teaching writing using the Internet increases positive interactivity for the teaching and learning of sentence grammar (Yunus, Nordin, Salehi, Embi, \& Salehi, 2013). Moreover, students' writing quality is surely improved due to their effort to communicate understandably in the text-based online environment. From the interaction in online learning environment, students enrich their knowledge as well as their language complexities. Khalsi (2012) has proven that language complexities constructed in online learning environment which tend to engender various ideas, opinions and viewpoints are significantly correlated with knowledge construction. Consequently, knowledge construction leads to negotiation process and higher order thinking which improves students' writing quality. The finding also revealed that Internet-based teaching of writing increases students' writing quantity in which the length of the texts that the students write increases. This statement confirms Khalsi's (2013) research finding which shows that writing more frequent and longer postings in online environment tend to foster students' higher order thinking. In short, the more frequent the participation in the Internet-based teaching of writing, the higher the knowledge construction is.

The EFL teachers' responses suggested that the Internet-based teaching of writing promotes students to be active learners who independently search for online information to support their ideas and active learner who work collaboratively. The massive stocks of information in the Internet provide students with sufficient sources in improving their writing. This is in line with the existing research that shows that the Internet supports students to be active learners in providing new sources and means of obtaining information to support students' writing (Sahin et al., 2010). We do not neglect the fact that there must be a difference in students' writing between those who take sources from the Internet to support their writing and those who genuinely use their own thinking and diction in writing. Aside from the potentials of plagiarism from Internet-based sources, we believe that resources from the Internet are helpful to scaffold students' writing quality. In addition, the students also become active learners who work collaboratively by working in teams and using the Internet to search information, exchange ideas and publish results (Blackstone et al., 2007; Eady \& Lockyer, 2013). By becoming active learners, students are involved in student-centered learning. Student-centered learning is the goal of today's education for it leads to self-regulated learning where students assume the responsibility of their own learning. In student-centered learning, active learning, student engagement, and student responsibility are the central concern (Darabi, 2006). By maximizing the potentials of Internet-based teaching of writing, Internet surely improves students' writing quality as well as prepares them to be ready to be the independent and lifelong learners.

Additional teachers' perception toward the use of Internet-based facilities in teaching of writing is its flexibility. Flexibility in terms of time and space is beneficial to enhance the teaching (Jeffrey, et al., 2014; Petrides, 2002; Yang, 2004). By using Internet-based facilities in learning process, teachers and students can implement blended learning in which they do not need to follow a rigid program by meeting face-to-face. The flexibility to set time and place to study is helpful in teaching writing. Students can take the advantages of Internet-based learning by using the time sufficiently in collecting resources, constructing the ideas, and composing their writing due to the extra time offered by the flexible nature of online learning.

Furthermore, technology impacts students' motivation in learning due to its inherent interesting nature. Blackstone et al. (2007) found that students are highly motivated by the blogging activities which are attractive and effective for improving their writing. Yunus and Salehi (2012) state that using Facebook boosts the students' motivation as well as confidence to make students more daring to use the language especially in a written form. Internet-based teaching of writing also boosts students' confidence by expanding broader audience to read their writings. Internet-based teaching of writing allows students to share their writing with a wider and more varied audience beyond just their classmates and teachers (Purcell et al., 2013). It encourages students to write their best since their writing products are accessible not only by their friends or classmates, but also teachers and other Internet users all over the world.

Teachers relatively have the same opinion regarding the benefits of Internet-based teaching of writing and some of them have used email, online magazine, Facebook, MyiZonelab, blogs, and mailing list for various purposes 
in the teaching of writing. In addition, the rest of the inexperienced teachers are eager to use Twitter, Facebook, or Kaskus for prewriting activity, blog or Facebook for discussion and peer-feedback, and Email or Yahoo! Messenger to publish students' writing product. However, almost one third of the teachers did not use Internet in their teaching writing practice. This is surprising since the majority of the teachers are really familiar with social media such as Facebook and personal account such as Yahoo! Messenger in their daily activities. This implies that the use of Internet-based teaching of writing actually is not burdensome because it does not go beyond the teachers' daily life. Since using social media and personal accounts are ubiquitous things in the teachers' daily life, teaching of writing should not be an isolated way of teaching, but should be merged with the teaching practice instead. Therefore, one major concern we should note is how to motivate and instruct EFL teachers to integrate Internet-based facilities into their teaching writing practice.

\section{Conclusion}

This article has shown that the Internet-based teaching of writing is not a scarce practice in Indonesian EFL context of the teaching of writing. Despite of different background, place, and length of teaching English, the teachers view Internet-based teaching of writing as a potential in future teaching of writing. Aside from the various experiences the teachers have pertaining to the use of the Internet-based teaching of writing, the major findings show that the Internet-based teaching of writing has shaped student writing in myriad ways. As the teachers suggest, it improves students' writing quality and quantity, scaffolds active and independent learning, motivates students' learning, provides learning flexibility, and raises students' confidence. Regardless of their background and length of teaching, it seems obvious that the EFL teachers truly appreciated the need to improve their teaching writing practice and considered implementing Internet-based facilities in writing classes. Even though the Internet-based teaching of writing has huge benefits to students' writing, whether they can be used effectively in teaching writing still depends on how the teachers arranged the course. Teachers' role is vital, especially for students who are new to Internet-based learning. Therefore, it is crucial for teachers not only to acknowledge the potential of the Internet-based teaching of writing but also to encourage themselves to implement it in their own teaching practice. The results of this study also urge more intensive management and training to all teachers in various places in Indonesia to have the equal knowledge regarding the use of advanced technology in teaching, especially the use of internet for teaching writing. The future research might study the reasons behind teachers' reluctance of using Internet-based facilities in teaching writing or how to motivate teachers to integrate Internet-based facilities into their teaching writing practice.

\section{References}

Aliweh, A. M. (2011). The effect of electronic portfolios on promoting Egyptian EFL college students' writing competence and autonomy. Asian EFL Journal, 13(3), 90-132.

Aljumah, F., H. (2012). Saudi learner perceptions and attitudes towards the use of blogs in teaching English writing course for EFL majors at Qassim University. English Language Teaching, 5(1), 100-116. http://dx.doi.org/10.5539/elt.v5n1p100

Bani-Hani, N. A., Al-Sobh, M. A., \& Abu-Melhim, A. R. H. (2014). Utilizing Facebook groups in teaching writing: Jordanian EFL students' perceptions and attitudes. International Journal of English Linguistics, 4(5), 27-34. http://dx.doi.org/10.5539/ijel.v4n5p27

Bilal, H. A., Tariq, A. R., Din, N., Latif, H., \& Anjum, M. N. (2013). Investigating the problems faced by the teachers in developing English writing skills. Asian Journal Of Social Sciences \& Humanities, 52(3), 238-244.

Blackstone, B., Spiri, J., \& Naganuma, N. (2007). Blogs in English language teaching and learning: Pedagogical uses and student responses. Reflections on English Language Teaching, 6(2), 1-20.

Cahyono, B. Y., \& Widiati, U. (2007). Challenges and possibilities in the integration of the Internet in English teacher education. In M. K. Kabilan, \& M. E. Vethamani (Eds.), Internet and the English language classroom (pp. 187-209). Petaling Jaya, Malaysia: Sasbadi Sdn Bhd.

Catalog of the English Department. (2011). Malang: English Department, Faculty of Letters, State University of Malang.

Darabi, R. (2006). Basic writing and learning communities. Journal of Basic Writing, 25(1), 53-72.

Deore, K. V. (2012). The educational advantages of using internet. International Educational E-Journal, 1(2), $111-112$.

Eady, M. J., \& Lockyer, L. (2013). Tools for learning: Technology and teaching strategies. Queensland 
University of Technology, Australia, 71-92.

Erkan, D. Y., \& Saban, A., I. (2011). Writing performance relative to writing apprehension, self-efficacy in writing, and attitudes towards writing: A correlational study in Turkish tertiary-level EFL. Asian EFL Journal, 13(5), 163-191.

Ferris, D., \& Hedgcock, J. S. (1998). Teaching ESL composition. Mahwah, NJ: Lawrence Erlbaum.

Fidaoui, D., Bahous, R., \& Bacha, N. N. (2010). CALL in Lebanese elementary ESL writing classrooms. Computer Assisted Language Learning, 23(2), 151-168. http://dx.doi.org/10.1080/09588221003666248

Graham, S., \& Perin, D. (2007). Writing next: Effective strategies to improve writing of adolescents in middle and high schools - A report to Carnegie Corporation of New York. Washington, DC: Alliance for Excellent Education.

Gupta, D., \& Woldemariam, G. S. (2011). The influence of motivation and attitudes on writing strategy use of undergraduate EFL students: Quantitative and qualitative perspectives. Asian EFL Journal, 13(2), 34-89.

Hadjerrouit. S. (2011). A collaborative writing approach to Wikis: Design, implementation, and evaluation. Issues in Informing Science and Information Technology, 8, 431-449.

Hiew, W. (2012) English language teaching and learning issues in Malaysia: Learners' perceptions via Facebook dialogue journal. Journal of Arts, Science \& Commerce, 3, 1-9.

Jeffrey, L. M., Milne, J., Suddaby, G., \& Higgins, A. (2014). Blended learning: How teachers balance the blend of online and classroom components. Journal of Information Technology Education Research, 13, 121-140.

Khalsi, I. (2012). The effect of language complexity and group size on knowledge construction: Implications for online learning. Applied Research on English Language, 2(1), 69-76.

Khalsi, I. (2013). Analysis of an online debate: Examining social construction of knowledge in computer conferencing. $\quad$ Retrieved from https:/www.google.co.id/webhp?sourceid=chromeinstant\&ion=1\&espv=2\&ie=UT-8\#q=Khalsi $\% 2 \mathrm{C}+\mathrm{I} .+(20$ 13). + Analysis + of + an + Online + Debate $:+$ Examining + Social + Construction + of + Knowledge + in + Computer $+\mathrm{C}$ onferencing

Laborda, J. G., \& Royo, T. M. (2007). Bookreview: How to teach English with technology (A book by G. Dudeney \& N. Hockly). Educational Technology \& Society, 10(3), 320-324.

Legutke, M. K., Muller-Hartmann, A., \& Ditfurth, M. S. V. (2007). Preparing teachers for technology-supported ELT. In J. Cummins, \& C. Davison (Eds.), International handbook of English language teaching (pp. 1125-1138). New York: Springer. http://dx.doi.org/10.1007/978-0-387-46301-8_75

Lundin, R. W. (2008). Teaching with Wikis: Toward a networked pedagogy. Computers and Composition, 25, 432-448. http://dx.doi.org/10.1016/j.compcom.2008.06.001

Mohamed, K., \& Ayeche, Z. (2011). The impact of the internet on the development of students' writing. Revue des Sciences Humaines, 21, 51-63.

Moloudi, M. (2011). Online and face-to-face peer review: Measures of implementation in ESl writing classes. Asian EFL Journal, 52(1), 42-23.

Morehead, P., \& LaBeau, B. (2005). The continuing challenges of technology integration for teachers. Essays in Education, 15. Retrieved from http://www.usca.edu/essays/vol152005/moreheadrev.pdf

Petrides, L. A. (2002). Web-based technologies for distributed (or distance) learning: Creating learning-centered educational experiences in the higher education classroom. International Journal of Instructional Media, 29(1), 69-77.

Purcell, K., Buchanan, J., \& Friedrich, L. (2013). The impact of digital tools on student writing and how writing is taught in schools. Pew Research Center. Retrieved from http://www.pewInternet.org/files/old-media/Files/Reports/2013/PIP_NWP\%20Writing\%20and\%20Tech.pdf

Sahin, Y. G., Balta, S., Yasar, T., \& Ercan, T. (2010). The use of Internet resources by university students during their course projects elicitation: A case study. TOJET: The Turkish Online Journal of Educational Technology, 9(2), 234-244.

Warnock, S. (2009). Teaching writing online: How and why. Urbana, IL: National Council of Teachers of English. 
Wu, W. S. (2008). Using blogs in an EFL writing class. In S. Priya (Ed.), Netlingo: The metamorphosis of language (pp. 86-99). Hyderabad, India: The Lcfai University Press.

Yang, Y., \& Cornelius, L. F. (2004). Students' perception towards the quality of online education: A qualitative approach. Association for Educational Communication and Technology, 27, 861-877.

Yunus, M. M., Nordin, N., Salehi, H., Embi, M. A., \& Salehi, Z. (2013). The use of information and communication technology (ICT) in teaching ESL writing skills. English Language Teaching, 6(7), 1-8. http://dx.doi.org/10.5539/elt.v6n7p1

Yunus, M. M., \& Salehi, H. (2012). The effectiveness of Facebook groups on teaching and improving writing: Students' perceptions. Journal of Education and Information Technologies, 1(6), 87-96.

Yunus, M. M., Salehi, H., Sun, C. H., Yen, J. Y. P., \& Li, L. K. S. (2011). Using Facebook groups in teaching ESL writing. Recent Researches in Chemistry, Biology, Environment and Culture, 75(1), 75-80. 


\section{Appendix A}

Teachers' Pseudonym and Their Description

\begin{tabular}{|c|c|c|c|}
\hline No & Pseudonyms & Description & $\begin{array}{l}\text { Length of Teaching } \\
\text { English }\end{array}$ \\
\hline 1 & Tatik & $\begin{array}{l}\text { Tatik teaches English at a university in a small town in East } \\
\text { Java. }\end{array}$ & Less than five years \\
\hline 2 & Miko & Miko teaches English at the state University in Timor Island & Five to ten years \\
\hline 3 & Dina & $\begin{array}{l}\text { Dina teaches at University level student in Banjarmasin, } \\
\text { South Kalimantan. }\end{array}$ & Less than five years \\
\hline 4 & Elva & $\begin{array}{l}\text { Elva teaches at University level student in Banjarmasin, South } \\
\text { Kalimantan. }\end{array}$ & Less than five years \\
\hline 5 & Asfi & $\begin{array}{l}\text { Asfi teaches English at a private university in small town in } \\
\text { East Java. }\end{array}$ & Less than five years \\
\hline 6 & Agam & $\begin{array}{l}\text { Agam is an English instructor in an English course in a small } \\
\text { town in East Java }\end{array}$ & Less than five years \\
\hline 7 & Wigi & $\begin{array}{l}\text { Wigi is an English lecturer in a state University in one of } \\
\text { famous University in Malang }\end{array}$ & Five to ten years \\
\hline 8 & Rana & $\begin{array}{l}\text { Rana is an English lecturer in a public University in South } \\
\text { Kalimantan }\end{array}$ & Less than five years \\
\hline 9 & Sherly & $\begin{array}{l}\text { Sherly is an English lecturer in a public University in east } \\
\text { Java }\end{array}$ & Less than five years \\
\hline 10 & Teti & Teti is an English lecturer in a private University & Less than five years \\
\hline 11 & Erra & $\begin{array}{l}\text { Erra is an English lecturer in a state university in } \\
\text { Banjarmasin, East Kalimantan. }\end{array}$ & Less than five years \\
\hline 12 & Ruzki & Ruzky is an elementary school in Malang, East Java. & Less than five years \\
\hline 13 & Malia & Malia is an English lecturer in a private university in Malang. & More than ten years \\
\hline 14 & Dyan & $\begin{array}{l}\text { Dyan is an English instructor in an English course in Malang, } \\
\text { East Java. }\end{array}$ & Five to ten years \\
\hline 15 & Meira & An English lecturer in a private university in Malang & Five to ten years \\
\hline 16 & Sakir & Sakir is an English lecturer in a public university in Makassar. & Five to ten years \\
\hline 17 & Raza & Raza is an English lecturer in private university in Malang. & Less than five years \\
\hline
\end{tabular}

*Indonesia is an archipelago which has more than 17.000 islands. The University where the study was conducted is in the Province of East Java. Some of the teachers participating in this study come from various parts of the country.

\section{Copyrights}

Copyright for this article is retained by the author(s), with first publication rights granted to the journal.

This is an open-access article distributed under the terms and conditions of the Creative Commons Attribution license (http://creativecommons.org/licenses/by/3.0/). 